\title{
Effect of Irrigation Intervals on Growth and Productivity and Some Water Relations of Some Tomato Hybrids Grown Under Saline Soil Conditions
}

\author{
Bard, L. A., M.H.M, Mohamed, H.M. Elkoumy* and H.S.S. El- Shafay* \\ Horticulture Dept., Fac. Of Agric., Benha university and* Hort. Res. Institute, Agriculture Research Center, \\ Egypt.
}

\begin{abstract}
Two field experiments were carried out during the two successive summer seasons of 2017 and 2018 in a private sector farm at Kafr El-Sheikh Governorate, to investigate the effect of four irrigation intervals (every 10days, 15ays, 20ays and 25days) on vegetative growth, chemical composition, fruit yield and quality of some tomato hybrids (Alissa F1, Carmen F1and Super strain B) and also their interactions under saline soil conditions. The study included 12 treatments which were resulted from the combinations between four irrigation treatments (Irrigation every 10 days, 15 days, 20 days and 25 days and three tomato hybrids (Alissa F1, Carmen F1and Super strain B). Results clearly showed that using irrigation every $10\left(2850 \mathrm{~m}^{3} / \mathrm{fed}\right)$ and 15 days (2550 $\mathrm{m}^{3} / \mathrm{fed}$ ) with Super strain B reflected the highest values vegetative growth aspects of tomato plants and increased plant height, number of branches and leaves /plant and fresh and dry weight of plant as well as leaves area ,chlorophyll content, N, P, K, and proline, In addition, both fruit yield per plant and feddan as well as marketable fruit yield were increased, while unmarketable yield was decreased as a result of interaction treatments. The quality trait of tomato fruits i.e.., average fruit weight,length,diameter, fruit firmness,T.S.S., vitamin C and total acidity were increased.
\end{abstract}

Keywords: Tomato - salinity -irrigation intervals - tomato hybrids- fruit yield- fruit quality

\section{Introduction}

Tomato (Solanum lycopersicum Mill) is the most popular and widely grown solanaceae vegetable crop in Egypt. In each corner of the world, the major producers of tomatoes were the United States, Turkey, Egypt, India and Italy. Egypt produces 6723250 ton yearly the average devoted for tomato planting 395571 fed with an average 16.90 ton/fed. according to the statistics of Ministry of Agriculture 2017. Tomatoes are popular for their culinary properties and their health benefits. Tomatoes and tomato plantingbased products account for more than $85 \%$ of the dietary lycopene. Consumers demand tomatoes for many of their original characteristics. This means maintaining the color, nutritional content and level of antioxidant compounds present in the fresh fruits. These fruits include vitamins A, C, E and carotenoids such as beta- carotene and lycopene. Tomato production is limited by many environmental such as soil salinity, soil fertility, water quality, irrigation method and meteorological factors like temperature, relative humidity and wind speed. Productivity and quality depend upon the chosen cultivar and other factors which are related to soil characteristics and farming practices.

The application of deficit irrigation and kaolin suspension might be some of the options for mitigation negative effects of drought caused by climate change and for saving water in agricultural production. The application of deficit irrigation aims to save irrigation water, increase water use efficiency and achieve optimal yields (Topucet al., 2007). By applying the strategy of deficit irrigation, crops are systematically exposed to moderate levels of stress due to a lack of water for a certain period or during the entire vegetation, which results in lowering yields, but also to cost saving and increasing efficiency of water use (Pereira et al., 2002). Basically, the method of deficit is to reduce amount of applied irrigation water to such extent to cause the adaptive response of plants to drought, enabling them to increase the efficiency of water use and maintain yields, while increasing the quality of fruits (Savic, 2008). Before a decision is made on the application of deficit irrigation regimes, it is important toassess its impact on different cultures on the basis of many years of experimental research(Lgbadumet al., 2008).

IN Egypt, it is necessary to produce the maximum yield and profit from unit area by using available water efficientlybecause theexisting agricultural land and irrigationwater arerapidly diminishing.Consequently, it is important tofind ways by which available watercould beeconomically utilized. One way, to achieve thisgoal, is to reduce thetranspiration rate.The goal of deficit irrigation is to increase crop water use efficiency (WUE) by reducing the number of irrigation events ( Kirda , 2002 ). The DI process irrigates the root zone with less water than that required for evapotranspiration and makes use of suitable irrigation schedules, which are usually derived from field trails (Owes and Hachum, 2001). Egypt suffers from shortage of water. So, rationalization of irrigation water in this sector becomes amust.

Therefore, the main target for this present study was to investigate the effect of four irrigation intervals (every 10days, 15ays, 20ays and 25days) on vegetative growth, chemical composition, fruit yield and quality of some tomato hybrids (Alissa F1, Carmen F1and Super strain B) and also their interactions under saline soil conditions. 


\section{Materials and Methods}

Two field experiments were carried out during the two successive summer seasons of 2017 and 2018 in a private sector farm at Kafr El-Sheikh Governorate, to investigate the effect of irrigation intervals on vegetative growth, chemical composition , fruit yield and quality and some water relations of some tomato hybrids (Solanum lycopersicunMill) and also their interactions under Kafr El-Sheikh Governorate conditions.
The soil of the experimental field was clay in texture with $\mathrm{pH}$ 7.39. Soil samples were taken at 30 $\mathrm{cm}$ from soil surface and soil physical and chemical properties were determined according to Jackson (1973) and Black et al.(1982) and were illustrated at Table (a). Moreover, maximum and minimum air temperature (c0) and relative humidity \% Kafr ElSheikh region during two seasons of study. are shown in Table (b).

Table a. Average mechanical and chemical analyses of theexperimental soil during the two seasons of growth.

Physical analysis

Chemical analysis

\begin{tabular}{|c|c|c|c|c|c|}
\hline & & \multicolumn{2}{|c|}{ Cations meq/l } & \multicolumn{2}{|c|}{ Anions meq/l } \\
\hline Coarse sand & $18.3 \%$ & $\mathrm{Ca}^{++}$ & 5.40 & $\mathrm{CO}^{--}$ & ---- \\
\hline Fine sand & $12.8 \%$ & $\mathrm{Mg}^{++}$ & 4.54 & $\mathrm{HCO}^{-}$ & 2.00 \\
\hline Silt & $13.5 \%$ & $\mathrm{Na}^{+}$ & 15.55 & $\mathrm{Cl}^{-}$ & 14.79 \\
\hline Clay & $55.4 \%$ & $\mathrm{~K}^{+}$ & 0.11 & $\mathrm{SO}^{--}$ & 8.81 \\
\hline Texture class & clay & & & & \\
\hline Soil pH (1: 2.5 soil water suspension) & 7.39 & Available N & & $23.9 \mathrm{mg} / \mathrm{kg}$ & \\
\hline E.C, $\mathrm{dS} / \mathrm{m}$ & 2.56 & Available P & & $12.6 \mathrm{mg} / \mathrm{kg}$ & \\
\hline Organic matter & $2.6 \%$ & Available $\mathrm{K}$ & & $183 \mathrm{mg} / \mathrm{kg}$ & \\
\hline
\end{tabular}

Table b. Monthly air temperature and relative humidity in Kafr El-Sheikh region during two seasons of study.

\begin{tabular}{ccccccc} 
& \multicolumn{3}{c}{$\mathbf{2 0 1 7}$} & \multicolumn{2}{c}{$\mathbf{2 0 1 8}$} \\
\cline { 2 - 7 } & \multicolumn{2}{c}{ Tmperature $^{\circ} \mathbf{C}$} & R.H\% & \multicolumn{2}{c}{ Tmperature ${ }^{\circ} \mathbf{C}$} & \multicolumn{2}{c}{ R.H\% } \\
\hline Months & Max & Min & Average & Max & Min & Average \\
\hline March & 18.3 & 6.5 & 70 & 19.3 & 7.2 & 69 \\
\hline April & 27.1 & 10.1 & 65 & 25.3 & 10.3 & 64 \\
\hline May & 30.9 & 15.6 & 64 & 30.4 & 16.6 & 63 \\
\hline June & 34.1 & 18.3 & 61 & 32.7 & 19.7 & 60 \\
\hline July & 37.6 & 19.6 & 65 & 37.6 & 22.5 & 67 \\
\hline
\end{tabular}

The area of the experimental sub plot was $10.5 \mathrm{~m}^{2}$.Each experimental plot included four ridges 3.5 meters in long and 1 meter in width. From which, three ridges were planted and one was left as a guard between plots to prevent water movement from any plot to adjacent one. Transplanting was done on one side of ridge at $50 \mathrm{~cm}$ apart between seedlings. Transplanting was done on $7^{\text {th }}$ and $9^{\text {th }}$ of March in 2017 and 2018, respectively. All agriculture practices were done as recommended by Ministry of Agriculture and land reclamation for the crop and the studied area.

The experiment included 12 treatments which were the combinations of four irrigation treatments and three tomato hybrids as follow:

A-Irrigation intervals.

The irrigation intervals used in this experimental were as follows:
1- Irrigation every 10 days (10 - days).

2- Irrigation every 15 days (15 - days).

3- Irrigation every 20 days (20 - days).

4- Irrigation every 25 days ( 25 - days).

The irrigation treatments began after transplanting irrigation.

\section{B - Tomato hybrids.}

The tomato hybrids used in this experiment were: -

1- Alissa F1

2- Carmen F1

3- Super strain B

In both seasons, split plot design with four replications was used in this experiment where the main plots were devoted to four irrigation intervals and sub plots were occupied by three tomato hybrids. The hybrids were distributed randomly in the subplots. 
Table c. The main characteristics of Tomato hybrid Alissa, Carmen and Super Strain B hybrid.

\begin{tabular}{|c|c|c|c|}
\hline $\begin{array}{l}\text { Hybrids } \\
\text { Characteristics }\end{array}$ & Alissa & Carmen & Super Strain B \\
\hline Growth habit & Determinant & Determinant & Determinant \\
\hline Vegetative growth & $\begin{array}{l}\text { Medium with moderate } \\
\text { cover for fruits. }\end{array}$ & $\begin{array}{l}\text { Medium with moderate } \\
\text { cover for fruits. }\end{array}$ & $\begin{array}{l}\text { Medium with moderate } \\
\text { cover for fruits. }\end{array}$ \\
\hline Cultivation date & $\begin{array}{l}\text { Spring and early summer } \\
\text { seasons. }\end{array}$ & $\begin{array}{l}\text { Spring and early summer } \\
\text { seasons. }\end{array}$ & $\begin{array}{l}\text { Spring and early summer } \\
\text { seasons. }\end{array}$ \\
\hline Ripening date & $\begin{array}{l}\text { 70-90 days (Medium) of } \\
\text { transplanting }\end{array}$ & $\begin{array}{l}85-90 \text { days(medium) of } \\
\text { transplanting }\end{array}$ & $\begin{array}{l}90 \text { days (Medium) of } \\
\text { transplanting }\end{array}$ \\
\hline Fruit characteristics & $\begin{array}{l}\text { Medium long shape- } \\
\text { high firmness- moderate } \\
\text { red color-avg. fruit } \\
\text { weight } 120-150 \mathrm{~g} \text {. }\end{array}$ & $\begin{array}{l}\text { Long shape }- \text { high } \\
\text { firmness- moderate red } \\
\text { color avg. fruit weight } \\
130-140 \mathrm{~g}\end{array}$ & $\begin{array}{l}\text { Medium Long shape - } \\
\text { high firmness }- \text { moderate } \\
\text { red color - avg. fruit weight } \\
140-160 \mathrm{~g} \text {. }\end{array}$ \\
\hline Tolerance & $\begin{array}{l}\text { - Good fruit setting in } \\
\text { high temperature. }\end{array}$ & $\begin{array}{l}\text { Nematode holds roots- } \\
\text { tomato mosaic virus }\end{array}$ & $\begin{array}{l}\text { - Good fruit setting in high } \\
\text { temperature. }\end{array}$ \\
\hline
\end{tabular}

\section{Data recorded:}

\section{a. Vegetative growth characteristics.}

Three plants were taken from each experimental plot as a representative sample after 70 days from transplanting and the following data were recorded. plant height, number of branches and leaves/plant, fresh and dry weight per plant and Leaf area/plant.

\section{b. Chemical composition of plant foliage:}

Total chlorophyll, carbohydrates, nitrogen, phosphorus, potassium, and proline content were determined according to Murquard and Timpton (1987), Cherry (1973), Pregl (1945), John (1970), Brown and Lilleland (1964) and Bates, et al., (1973), respectively.

At harvest mature fruits were picked along the harvesting season and the following data were recorded

Total fruit yield/fed: It was calculated using plot yield and plot area.

Fruit yield/plant: It was calculated form fruit yield/plot and number of plants/plots.

Marketable fruit yield/fed: it was calculated as weight of harvested fruits after discarding the misshaped fruits.

Unmarketable yield /fed: it was calculated as weight of infected and the misshaped fruits.

Early yield

Water use efficiency

Water use efficiency expressed as water economy, was calculated using the following equation of Begg and Turner (1976).

$$
\text { Water economy }\left(\mathrm{kg} / \mathrm{m}^{3}\right)=\frac{\text { Total yield }(\mathrm{kg} / \mathrm{fed} .)}{\text { Total amount of applied water }\left(\mathrm{m}^{3} / \mathrm{fed} .\right)}
$$

\section{d. Fruit quality}

1- Physical quality: A random sample of 10 fruits at full ripe stage from each experimental plot was taken to determine the following properties. Average fruit weight, length, diameter and firmness. Fruit firmness $\left(\mathrm{g} / \mathrm{cm}^{2}\right)$ was determined by using digitalis Penetrometer (PCE-PTR.MITPC, USA) with a needle $8 \mathrm{~mm}$ in diameter.

\section{Chemical quality:}

Total soluble solids (T.S.S.): A random sample of 10 fruits from each experimental plot at full ripe stage was taken to determine the percentage of soluble solid content by using the hand refractometers.

Total titratable acidity (T.T. A) and L. ascorbic acid were determined according to the method described in A. O. A.C. (1990).

\section{4- Statistical analysis:}

The analysis of variance was carried out according to Gomez and Gomez (1984). Treatment means were compared by Duncan's Multiple Rang Test (Duncan, 1955). Statistical analysis of variance was done using COSTAT software package.

\section{Results and Discussion}

\section{1- Vegetative growth characteristics.}

Data recorded in Table (1) show the effect of irrigation intervals ( 10 days -15 days -20 days and 25 days) and hybrids ,i.e, Alissa, Carmen and Super strain B as well as their interaction on vegetative growth aspects of tomato plants grown under Kafr El-sheikh condition during the two seasons of study

Concerning the effect of irrigation intervals data in Table (1) showed that irrigation every 10 days followed by irrigation every 15 days( irrigation at soil moisture content of field capacity) during the growing season recorded the highest values of vegetative growth and increased all measured vegetative growth parameters without significant differences between them expressed as number of branches and leaves per plant, fresh and dry weight of 
plant and leaves area compared with other irrigation treatments under study in both seasons. While, plant height was significantly and steadily increased with increasing the rate of irrigation water during the growing seasons. On the other hand, the irrigation every 25 days (irrigation at soil moisture content of field capacity) recorded the lowest values of all measured vegetative growth traits in both seasons of study. This result are true in both seasons of study. Such increments in vegetative growth traits due to increasing the level of irrigation may be due to the role of water in accelerating the physiological processes and increasing the solubility and up-take of macroand micro- nutrients which constitute and incorporated in the formation of protoplasmic materials necessary for cells formation and consequently increasing the vegetative growth of plant. Obtained results are in agreement with those reported by Abdalalliet al.(2012), Abd El-hadyet al.(2017) and Malashet al.(2019) they reported that drought stress significantly decreased most vegetative growth characteristics.

The same data in table (1) indicated that there were significant differences among the tested hybrids in all vegetative growth characteristics, i.e. plant height, number of branches and leaves, fresh and dry weight of plant as well as plant leaves area during both seasons of study. In this regard, super strain B and Alissa hybrids gives the highest values of all measured vegetative growth characteristics with no significant differences between them except plant height in both seasons of study. While Carmen hybrid gave the highest values of plant height in both seasons of study compared with other cultivars under study. Such differences among the tested hybrids in vegetative growth aspects maybe attributed to the genetic differences for such hybrids. In this concern, Boagleet al (2016), Pazzagliet al (2016), Aghaieet al (2018) reported that there are highly variation among tomato cultivars for all vegetative growth parameters.

As for the effect of the interaction treatments between irrigation intervals and cultivars, the same data in table (1) revealed that the highest values in all measured growth traits were recorded as a result of using irrigation every 10 days ( $2850 \mathrm{~m}^{3}$ water/fed) followed by irrigation every 15 days ( $2550 \mathrm{~m}^{3}$ water/fed) with cultivars super strain B and Alissa with no significant differences between them for number of branches and leaves /plant, fresh and dry weight per plant and leaves area in both seasons . While Carmen hybrid recorded the tallest plants when irrigated every 10 days in the two seasons. On the other hand, irrigation every $25\left(2100 \mathrm{~m}^{3}\right.$ water/fed $)$ days recorded the lowest values for all measured vegetative growth characteristics with all cultivars especially Carmen hybrid in both seasons of study.

\section{Chemical composition of plant foliage :-}

Concerning the effect of irrigation levels on total chlorophyll reading, proline (mg/100g dry weight), total carbohydrates (mg/100g d.w), N\%, P\% and K\% of tomato plant foliage, data given in table (2) indicated clearly that irrigated tomato plants every 10days ( irrigation at soil moisture content of field capacity) followed by 15 days( irrigation at soil moisture content of field capacity) during the two seasons of growth gives the maximum values and increased all assayed chemical constituents of plant foliage i.e, total chlorophyll reading and macro elements (N,P,K percentage ) without significant differences between them except proline and carbohydrates content in both seasons of study. On the other hand, irrigation every 25 days ( irrigation at soil moisture content of field capacity) gives higher proline and carbohydrates content compared with other irrigation treatments under study and in the same time recorded the lowest values of chlorophyll reading and N.P.K. percentage in both seasons. In this respect, the reduction of total chlorophyll reading and NPK concentration in plant foliage as a result of increasing the irrigation rate may be due the increasing of absorbed and translocated water to the foliage of plant parts, which in turn diluted such concentration of macro- nutrients in foliage cells of plants. Similar results were obtained by numerous of investigator,Abdala aliet al. (2012), ElZawilyetal.(2019), Jiansheet al. (2019) and Malashet al. (2019).

With regarding the effect of cultivars, the same data in Table (2) revealed that the highest values of all measured chemical constituents (total chlorophyll reading, $\mathrm{N}, \mathrm{P}$ and $\mathrm{K}$ ) except proline and carbohydrate were recorded by Super strain B and Alissa cultivars without significant differences between them in both seasons of study. While, Carmen cultivar recorder the higher proline and carbohydrates content than other cultivars ( Super strain B , and Alissa cultivars) and the lowest values of total chlorophyll reading, N, $\mathrm{P}$ and $\mathrm{K}$ in both seasons of study. The difference in chemical constituents in tomato plants could may be connected with te differences in growth rate (table,2) and the differences in their nutrient requirements and absorbing ability of different tested hybrids. More ever it may be due to the genetic differences in genetic potential for such tested hybrids. Similar results were reported by Kim Hain et al.(2014) and Aghaieet al (2018). 
Table 1. Effect of irrigation intervals, hybrids and their interaction on vegetative growth characteristics of tomato plants grown under Kafr-Elsheikh condition during 2017 and 2018 summer seasons.

\begin{tabular}{|c|c|c|c|c|c|c|c|c|c|c|c|c|c|}
\hline \multirow{3}{*}{$\begin{array}{l}\text { Treatments } \\
\text { Irrigation } \\
\text { intervals } \\
\end{array}$} & \multirow{3}{*}{$\begin{array}{l}\text { Characters } \\
\text { Hybrids }\end{array}$} & \multirow{2}{*}{\multicolumn{2}{|c|}{$\begin{array}{c}\begin{array}{c}\text { Plant height } \\
(\mathrm{cm})\end{array} \\
\text { Seasons } \\
\end{array}$}} & \multirow{2}{*}{\multicolumn{2}{|c|}{$\begin{array}{c}\begin{array}{c}\text { No. of } \\
\text { branches/plant }\end{array} \\
\text { Seasons } \\
\end{array}$}} & \multirow{2}{*}{\multicolumn{2}{|c|}{$\begin{array}{c}\text { No. of leaves /plant } \\
\text { Seasons }\end{array}$}} & \multirow{2}{*}{\multicolumn{2}{|c|}{$\begin{array}{c}\begin{array}{c}\text { Fresh weight } \\
\text { (g/plant) }\end{array} \\
\text { Seasons } \\
\end{array}$}} & \multirow{2}{*}{\multicolumn{2}{|c|}{$\begin{array}{c}\begin{array}{c}\text { Dry weight ( } \\
\text { g/plant) }\end{array} \\
\text { Seasons } \\
\end{array}$}} & \multirow{2}{*}{\multicolumn{2}{|c|}{$\begin{array}{c}\begin{array}{c}\text { Leaves area } \\
\left(\mathrm{cm}^{2} / \text { plant }\right)\end{array} \\
\text { Seasons } \\
\end{array}$}} \\
\hline & & & & & & & & & & & & & \\
\hline & & 2017 & 2018 & 2017 & 2018 & 2017 & 2018 & 2017 & 2018 & 2017 & 2018 & 2017 & 2018 \\
\hline 10 days & & $77.58 \mathrm{a}$ & $78.50 \mathrm{a}$ & $5.91 \mathrm{a}$ & $6.08 \mathrm{a}$ & $58.54 \mathrm{a}$ & 59.75 a & $465.16 \mathrm{a}$ & $481.25 \mathrm{a}$ & $71.33 \mathrm{a}$ & $74.33 \mathrm{a}$ & $4282.5 \mathrm{a}$ & $4325 \quad a$ \\
\hline 15 days & & $74.79 \mathrm{~b}$ & $74.16 \mathrm{~b}$ & $5.75 \mathrm{a}$ & $5.87 \mathrm{a}$ & $57.33 \mathrm{a}$ & 58.33 a & $465.83 \mathrm{a}$ & $480.00 \mathrm{a}$ & 70.5 a & $73.5 \mathrm{a}$ & $4252.08 \mathrm{a}$ & 4291.66 a \\
\hline 20days & & $71.79 \mathrm{c}$ & $72.41 \mathrm{c}$ & $5.08 \mathrm{~b}$ & $5.34 \mathrm{~b}$ & $53.20 \mathrm{~b}$ & $55.58 \mathrm{~b}$ & $435.00 \mathrm{~b}$ & $443.75 \mathrm{~b}$ & $67.5 \mathrm{~b}$ & $68.65 \mathrm{~b}$ & $4079.16 \mathrm{~b}$ & $4100 \quad b$ \\
\hline \multirow[t]{5}{*}{25 days } & & 64.08d & $63.58 \mathrm{~d}$ & $5.08 \mathrm{~b}$ & $5.33 \mathrm{~b}$ & $51.38 \mathrm{~b}$ & $52.00 \mathrm{c}$ & $309.16 \mathrm{c}$ & 312.91c & $61.66 \mathrm{c}$ & $63.75 \mathrm{c}$ & $3827.50 \mathrm{c}$ & 3854.16 c \\
\hline & Alisa & $69.65 \mathrm{~b}$ & $70.93 \mathrm{~b}$ & $5.56 \mathrm{a}$ & $5.75 \mathrm{a}$ & 56.03 a & 57.31 a & $431.31 \mathrm{a}$ & 438.12a & 70.06 a & $72.93 \mathrm{a}$ & 4246.87 a & 4281.25 a \\
\hline & Carmen & $74.75 a$ & $74.12 \mathrm{a}$ & $4.96 \mathrm{~b}$ & $5.12 \mathrm{~b}$ & $52.51 \mathrm{~b}$ & 52.12 b & $386.81 \mathrm{~b}$ & $405.18 b$ & $61.75 \mathrm{~b}$ & $64.18 \mathrm{~b}$ & 3853.12 b & $3881.25 \mathrm{~b}$ \\
\hline & Super strain B & 71.78 b & $71.43 \mathrm{~b}$ & $5.84 \mathrm{a}$ & $6.09 \mathrm{a}$ & $57.1 \mathrm{a}$ & 59.81 a & $438.25 \mathrm{a}$ & 445.12a & $71.43 \mathrm{a}$ & $73.12 \mathrm{a}$ & 4230.93 a & $4265.62 \mathrm{a}$ \\
\hline & Alisa & 75.25 abc & 76.75 bc & 5.87 a & $6 \mathrm{a}$ & $59.12 \mathrm{ab}$ & $61.5 \mathrm{~b}$ & $477 \mathrm{a}$ & $487.5 \mathrm{~b}$ & 73.75 a & 78 a & 4450 a & 4487.5 a \\
\hline \multirow{2}{*}{10 days } & Carmen & 80.5 a & 80.75 a & 5.25 a & $5.5 \mathrm{a}$ & 56 abc & 53.75 def & $423.5 \mathrm{~cd}$ & $445 \mathrm{~cd}$ & $64.75 \mathrm{~b}$ & $67.5 \mathrm{de}$ & 3950 bcd & $4000 \mathrm{~cd}$ \\
\hline & Super strain B & $77 \mathbf{a b}$ & $78 \mathrm{ab}$ & $6.62 \mathrm{a}$ & $6.75 \mathrm{a}$ & $60.5 \mathrm{a}$ & $64 a b$ & 495 a & 511.25 a & 75.5 a & 77.5 a & 4447.5 a & 4487.5 a \\
\hline \multirow{3}{*}{15 days } & Alisa & $\begin{array}{c}71.25 \\
\text { bed }\end{array}$ & $74.50 \mathrm{~cd}$ & 5.87 a & 6 a & 58.25 ab & $56.5 \mathrm{~cd}$ & $485 a$ & $487.5 \mathrm{~b}$ & 73.25 a & $76.25 \mathrm{ab}$ & 4412.5 a & $4462.5 \mathrm{ab}$ \\
\hline & Carmen & $76.62 \mathrm{ab}$ & $74.50 \mathrm{~cd}$ & 5.12 a & 5.12 a & 53.5 abc & 52.75 def & $418.75 \mathrm{~d}$ & $440.75 \mathrm{~cd}$ & 63 bc & 66.75 ef & 3925 bcd & 3950 cde \\
\hline & Super strain B & $76.50 \mathrm{ab}$ & $73.50 \mathrm{~cd}$ & $6.25 \mathrm{a}$ & $6.5 \mathrm{a}$ & $60.25 \mathrm{a}$ & $65.75 \mathrm{a}$ & $\begin{array}{c}493.75 \\
\text { bc } \\
\end{array}$ & 511.75 a & $75.25 \mathrm{a}$ & $77.5 \mathrm{a}$ & $4418.75 \mathrm{a}$ & $4462.5 \mathrm{ab}$ \\
\hline \multirow{3}{*}{20 days } & Alisa & 69 def & $69 \mathrm{e}$ & 5.25 a & $5.75 \mathrm{a}$ & 55.5 abc & 60.25 bc & $453.25 \mathrm{~b}$ & $462.5 \mathrm{c}$ & $71.25 \mathrm{a}$ & 72.5 bc & 4200 ab & 4225 abc \\
\hline & Carmen & $76.5 \mathrm{ab}$ & 76.25 bc & $5 \mathbf{a}$ & $4.75 \mathrm{a}$ & $49.62 \mathrm{c}$ & 52 ef & $411.25 d$ & $430 \mathrm{~d}$ & $60.5 \mathrm{bc}$ & $62.5 \mathrm{fg}$ & $3875 \mathrm{~cd}$ & 3900 de \\
\hline & Super strain B & 69.87 cde & 72 de & 5 a & $5.5 \mathrm{a}$ & 54.5 abc & 50.5 ef & 440.5 bc & $438.75 \mathrm{~cd}$ & 70.75 a & $71.25 \mathrm{~cd}$ & $\begin{array}{c}4162.5 \\
\text { abc }\end{array}$ & 4175 bcd \\
\hline \multirow{3}{*}{25 days } & Alisa & $63.12 \mathrm{~g}$ & $63.5 \mathrm{f}$ & $5.25 \mathrm{a}$ & $5.25 \mathrm{a}$ & 51.25 bc & 51 ef & 310 ef & 315 e & $62 \mathrm{bc}$ & 65 ef & 3925 bcd & 3950 cde \\
\hline & Carmen & 65.37 efg & $65 \mathrm{f}$ & $4.5 \mathrm{a}$ & $5.12 \mathrm{a}$ & $49.75 \mathrm{c}$ & $50 \mathrm{f}$ & 293.75 f & $305 \mathrm{e}$ & 58.75 c & $60 \mathrm{~g}$ & $3662.5 \mathrm{~d}$ & 3675 e \\
\hline & Super strain B & $63.75 \mathrm{fg}$ & $62.25 \mathrm{f}$ & $5.5 \mathrm{a}$ & 5.62 a & $\begin{array}{c}53.15 \\
\text { abc }\end{array}$ & 55 de & 323.75 e & $318.75 \mathrm{e}$ & $64.25 \mathrm{~b}$ & 66.25 ef & 3895 cd & 3937.5 cde \\
\hline
\end{tabular}


Table 2. Effect of irrigation intervals, hybrids and their interaction on chemical composition of tomato plant foliage grown under Kafr-Elsheikh condition during 2017 and 2018 summer seasons.

\begin{tabular}{|c|c|c|c|c|c|c|c|c|c|c|c|c|c|}
\hline \multirow{3}{*}{$\begin{array}{c}\text { Treatments } \\
\begin{array}{l}\text { Irrigation } \\
\text { intervals }\end{array}\end{array}$} & \multirow{3}{*}{$\begin{array}{l}\text { Characters } \\
\text { ybrids }\end{array}$} & \multirow{2}{*}{\multicolumn{2}{|c|}{$\begin{array}{c}\text { Chlorophyll reading } \\
\text { (SPAD unit) }\end{array}$}} & \multirow{2}{*}{\multicolumn{2}{|c|}{$\begin{array}{c}\begin{array}{c}\text { Proline } \\
\text { (mg/100gd.w })\end{array} \\
\text { seasons } \\
\end{array}$}} & \multirow{2}{*}{\multicolumn{2}{|c|}{$\begin{array}{c}\begin{array}{c}\text { Carbohydrates } \\
\text { (g/100gmd.w) }\end{array} \\
\text { seasons }\end{array}$}} & \multirow{2}{*}{\multicolumn{2}{|c|}{$\begin{array}{c}\mathbf{N} \% \\
\text { Seasons } \\
\end{array}$}} & \multirow{2}{*}{\multicolumn{2}{|c|}{$\begin{array}{c}\text { P \% } \\
\text { seasons }\end{array}$}} & \multirow{2}{*}{\multicolumn{2}{|c|}{$\begin{array}{c}\text { K \% } \\
\text { Seasons }\end{array}$}} \\
\hline & & & & & & & & & & & & & \\
\hline & & 2017 & 2018 & 2017 & 2018 & 2017 & 2018 & 2017 & 2018 & 2017 & 2018 & 2017 & 2018 \\
\hline 10 days & & 51.75 a & 53.27 a & $6.88 \mathrm{c}$ & $6.93 \mathrm{c}$ & $1.16 \mathrm{c}$ & $1.18 \mathrm{c}$ & $3.28 \mathrm{a}$ & $3.32 \mathrm{a}$ & 0.417 a & 0.429 a & 3.08 a & $3.10 \mathrm{a}$ \\
\hline 15 days & & 50.75 a & $52.00 \mathrm{a}$ & 7.10 bc & $7.16 \mathrm{~b}$ & $1.29 \mathrm{~b}$ & $1.36 \mathrm{~b}$ & $3.26 \mathrm{a}$ & $3.31 \mathrm{a}$ & 0.407 a & $0.423 \mathrm{a}$ & 3.06 a & $3.10 \mathrm{a}$ \\
\hline 20days & & $44.58 \mathrm{~b}$ & $48.00 \mathrm{~b}$ & $7.36 \mathrm{ab}$ & $7.39 \mathrm{a}$ & $1.42 \mathrm{a}$ & $1.43 \mathrm{a}$ & $3.16 \mathrm{~b}$ & $3.23 \mathrm{~b}$ & $0.375 \mathrm{~b}$ & $0.386 \mathrm{~b}$ & $2.94 \mathrm{~b}$ & $2.97 \mathrm{~b}$ \\
\hline \multirow{4}{*}{25 days } & & $41.91 \mathrm{c}$ & $43.83 \mathrm{c}$ & $7.42 \mathrm{a}$ & $7.45 \mathrm{a}$ & $1.42 \mathrm{a}$ & $1.45 \mathrm{a}$ & $2.87 \mathrm{c}$ & $2.95 \mathrm{c}$ & $0.316 \mathrm{c}$ & 0.327 c & $2.74 \mathrm{c}$ & $2.77 \mathrm{c}$ \\
\hline & Alisa & $48.25 \mathrm{a}$ & $50.33 \mathrm{a}$ & $7.42 \mathrm{a}$ & $7.45 \mathrm{a}$ & $1.49 \mathrm{~b}$ & $1.57 \mathrm{a}$ & $3.34 \mathrm{a}$ & $3.43 \mathrm{a}$ & 0.388 a & $0.402 \mathrm{a}$ & $3.33 \mathrm{a}$ & $3.37 \mathrm{a}$ \\
\hline & Carmen & $45.18 \mathrm{~b}$ & $47.37 \mathrm{~b}$ & $6.65 \mathrm{~b}$ & $6.71 \mathrm{~b}$ & 0.93 c & $1.08 \mathrm{c}$ & $2.54 \mathrm{~b}$ & $2.59 \mathrm{~b}$ & $0.342 \mathrm{~b}$ & $0.354 \mathrm{~b}$ & $2.21 \mathrm{~b}$ & $2.23 \mathrm{~b}$ \\
\hline & Super strain B & $47.56 \mathrm{a}$ & 50.12 a & $7.51 \mathrm{a}$ & $7.54 \mathrm{a}$ & $1.56 \mathrm{a}$ & $1.42 \mathrm{~b}$ & $3.56 \mathrm{a}$ & $3.59 \mathrm{a}$ & 0.406 a & 0.416 a & $3.33 \mathrm{a}$ & $3.35 \mathrm{a}$ \\
\hline \multirow[t]{3}{*}{10 days } & Alisa & 52.75 a & 54.32 a & $7.22 \mathrm{~cd}$ & $7.22 \mathrm{~b}$ & $1.30 \mathrm{~d}$ & $1.32 \mathrm{~d}$ & 3.45 bc & $3.52 \mathrm{ab}$ & 0.427 a & 0.445 a & $3.46 \mathrm{a}$ & $3.5 \mathrm{a}$ \\
\hline & Carmen & $50 \mathrm{c}$ & 51 bcd & $6.15 \mathrm{f}$ & $6.22 \mathrm{e}$ & 0.89 e & $0.91 \mathrm{e}$ & $2.64 \mathrm{e}$ & $2.66 \mathrm{~d}$ & 0.372 a & 0.385 a & $2.31 \mathrm{~b}$ & $2.32 \mathrm{~b}$ \\
\hline & Super strain B & 52.5 a & 54.5 a & $\begin{array}{l}7.27 \\
\text { bcd }\end{array}$ & $7.35 \mathrm{a}$ & $1.31 \mathrm{~d}$ & $1.32 \mathrm{~d}$ & $3.75 \mathrm{a}$ & 3.76 a & 0.452 a & 0.457 a & 3.48 a & $3.48 \mathrm{a}$ \\
\hline \multirow[t]{3}{*}{15 days } & Alisa & $51 \mathrm{~b}$ & $53.25 \mathrm{ab}$ & $\begin{array}{l}7.36 \\
\text { bcd }\end{array}$ & $7.42 \mathrm{a}$ & $1.44 \mathrm{c}$ & $1.52 \mathrm{~b}$ & $3.43 \mathrm{bc}$ & $3.47 \mathrm{ab}$ & 0.417 a & 0.437 a & $3.43 \mathrm{a}$ & 3.48 a \\
\hline & Carmen & $47.5 \mathrm{~d}$ & 50.5 cde & $6.42 \mathrm{f}$ & $6.5 \mathrm{~d}$ & $0.90 \mathrm{e}$ & $1.45 \mathrm{c}$ & 2.61 ef & $2.70 \mathrm{~d}$ & 0.365 a & 0.382 a & $2.29 \mathrm{~b}$ & $2.32 \mathrm{~b}$ \\
\hline & Super strain B & 50.75 bc & 52.25 bc & $7.52 \mathrm{abc}$ & $7.57 \mathrm{a}$ & $1.52 \mathrm{bc}$ & $0.92 \mathrm{e}$ & 3.73 a & $3.8 \mathrm{a}$ & 0.440 a & $0.450 \mathrm{a}$ & $3.45 \mathrm{a}$ & $3.48 \quad \mathrm{a}$ \\
\hline \multirow[t]{4}{*}{20 days } & Alisa & $46.25 \mathrm{de}$ & 48.25 ef & $7.53 \mathrm{abc}$ & $7.55 \mathrm{a}$ & $1.6 \mathrm{~b}$ & $1.6 \mathrm{~b}$ & $3.35 \mathrm{~cd}$ & $3.42 \mathrm{ab}$ & 0.377 a & 0.390 a & $3.32 \mathrm{a}$ & $3.37 \mathrm{a}$ \\
\hline & Carmen & $42.75 \mathrm{~g}$ & $46.25 \mathrm{fg}$ & 7.16 de & $7.2 \mathrm{~b}$ & $0.96 \mathrm{e}$ & 0.97 e & 2.52 ef & $2.57 \mathrm{~d}$ & $0.340 \mathrm{a}$ & 0.350 a & $2.18 \mathrm{~b}$ & $2.2 \mathrm{~b}$ \\
\hline & Super strain B & 44.75 ef & 49.5 ef & $7.58 \mathrm{a}$ & $7.62 \mathrm{a}$ & $1.7 \mathrm{a}$ & $1.72 \mathrm{a}$ & $3.63 \mathrm{~b}$ & $3.7 \mathrm{a}$ & 0.407 a & 0.420 a & 3.32 a & $3.35 \mathrm{a}$ \\
\hline & Alisa & $43 \mathrm{fg}$ & $45.5 \mathrm{~g}$ & $7.57 \mathrm{a}$ & $7.62 \mathrm{a}$ & $1.62 \mathrm{~b}$ & $1.65 \mathrm{~b}$ & $3.12 \mathrm{~d}$ & $3.3 \mathrm{bc}$ & 0.330 a & 0.330 a & $3.09 \mathrm{a}$ & $3.12 \mathrm{a}$ \\
\hline \multirow[t]{2}{*}{25 days } & Carmen & $40.5 \mathrm{~h}$ & $41.75 \mathrm{~h}$ & $6.87 \mathrm{e}$ & $6.92 \mathrm{c}$ & $0.96 \mathrm{e}$ & $0.98 \mathrm{e}$ & $2.37 \mathrm{f}$ & $2.42 \mathrm{~d}$ & $0.292 \mathrm{a}$ & 0.300 a & $2.06 \mathrm{~b}$ & $2.1 \quad b$ \\
\hline & Super strain B & $42.25 \mathrm{gh}$ & $44.25 \mathrm{~g}$ & 7.65 a & $7.63 \mathrm{a}$ & $1.73 \mathrm{a}$ & $1.73 \mathrm{a}$ & $3.12 \mathrm{~d}$ & $3.12 \mathrm{c}$ & 0.327 a & 0.340 a & 3.07 a & $3.1 \mathrm{a}$ \\
\hline
\end{tabular}


As for the effect of the interaction treatments between irrigation intervals and cultivars, the same data in table (2) showed clearly that under irrigation every $10\left(2850 \mathrm{~m}^{3} / \mathrm{fed}\right)$ and 15 days $\left(2550 \mathrm{~m}^{3} / \mathrm{fed}\right)$, the hybrids Super strain B and Alissa recorded the highest values of all chemical constituents of plant foliage ( chlorophyll reading, N,P and $\mathrm{K}$ ) in both seasons of study. However, Carmen hybrid was the lowest chemical constituents ( chlorophyll reading , $\mathrm{N}, \mathrm{P}$ and $\mathrm{K}$ ) in both seasons of study. On the other hand, irrigation every 25days $\left(2100 \mathrm{~m}^{3} / \mathrm{fed}\right)$ followed by 20 days $\left(2150 \mathrm{~m}^{3} / \mathrm{fed}\right)$ plots planted with Carmen plants recorded the highest values of proline and carbohydrates content and recorded the lowest values of chemical constituents (chlorophyll reading, N,P and K) in 2017 and 2018 seasons.

\section{Fruit yield and its components as wellas water use efficiency.}

Data presented in table 3 showed that total produced fruit yield and its components expressed as early and total fruit yield per plant, marketable and unmarketable fruit yield as well as total fruit yield per fedden were significantly affected as a result of irrigation intervals treatments. In this respect, the plants irrigated every 10 days (irrigation at soil moisture content. of field capacity) and 15 days (irrigation at soil moisture content. of field capacity) during growing seasons significantly increased and produced early and total fruit yield per plant as well as marketable and total fruit yield /fed without significant differences between them, However it decreased the unmarketable fruit yield compared with other irrigation treatments under study. In this regard, using irrigation every 10 and 15 days exhibited the highest values of early yield per plant, total fruit yield for both plant and feddan as well as marketable fruit yield compared with other tested irrigation treatments in both seasons of study . In this respect, irrigation every 15 days (irrigation at soil moisture content of field capacity) recorded the highest values of water use efficiency in both seasons compared with other irrigation treatments under study. On the other hand, irrigation every 25 days( irrigation at soil moisture content of field capacity) recorded the lowest values of fruit yield and its components except unmarketable yield, its increased by using irrigation every 25 days in both seasons compared with other irrigation treatments in this study. Such increments in total fruit yield and its components due to increasing the amounts of irrigation applied are connected with the enhancing effect of irrigation water on vegetative growth of plant (table1) which in turn affect on the yielding ability of plants. These finding are in agreement with those obtained by previouslyWahb-Allah and Al-Omran(2012), Zhu et al.(2012), Monte et al.(2013), Rahil et al.(2013) and Luvaiet al.(2014) all working on tomato.

Concerning the effect of cultivars on total fruit yield and its components as well as water use efficiency, the same data in table (7) indicated that total fruit yield and its components asearly and total fruit per plant, marketable and unmarketable fruit yield and total fruit yield and per feddan. Water use efficiency were significantly affected and increased by cultivar plots with Super stain B followed by Alissa under this study in both seasons. On the other hand, plots cultivated with Carmen hybrid recorded the lowest values of fruit yield and its components as well as water use efficiency in2017 and 2018 seasons. Such findings might be due to genetic make - up of the cultivars.Also, such differences in fruit yield and its components as well as water use efficiency among the tested cultivars may be due to the differences in vegetative growth (table 1). Similar varietal differences in early and fruit per plant, marketable and unmarketable fruit yield and total fruit yield were recorded by Bogaleet al.(2016)andCruzet al.(2019). With respect to the effect of the interaction treatments , data in table (3) coincided that using irrigation every $10\left(2850 \mathrm{~m}^{3} / \mathrm{fed}\right)$ and 15 days $\left(2550 \mathrm{~m}^{3} / \mathrm{fed}\right)$ with Super strain B reflected the highest values of fruit yield and its components ( early and total fruit yield per plant, total yield and marketable yield per feddan) with no significant differences between them in both seasons except unmarketable yield per feddan . In addition, irrigation every 15 days with Super strain B cv. recorded significantly the highest values for water use efficiency in both seasons of study. On the other hand, irrigation every 25 days( $2100 \mathrm{~m}^{3} / \mathrm{fed}$ ) with all cultivars recorded the lowest values of fruit yield and it components (early and total fruit yield per plant, marketable and unmarketable fruit yield and total fruit yield per feddan ) as well as water use efficiency in 2017 and 2018 seasons.

\section{Physical fruit quality.}

Regarding the effect of irrigation intervals treatments on physical fruit quality of tomato expressed as average fruit weight, length, diameter and fruit firmness, data in table (4) indicated that all foregoing physical fruit quality traits were significantly increased as a result of using irrigation every 10 and 15 days ( irrigation at soil moisture content and \% of field capacity, repectively) compared with other treatments under study .More ever, using irrigation every 10 and 15 days recorded the highest values in all measured physical fruit quality traits without significant differences between them except fruit firmness in both seasons of study. On the other hand, irrigation every 25 days( irrigation at soil moisture content and \% of field capacity) recorded the highest values of fruit firmness and in the same time its decreased the fruit weight and fruit length in both seasons. While, the fruit diameter were not significantly affected in both seasons of study. Such improvement in physical fruit traits as a result of using irrigation intervals treatments may be due to the increase in photosynthetic pigments and mineral 
elements content of plant foliage (table 2) which affected positively on plant growth( table 1) and consequently on quality of produce fruit (table 3 ) as well as the main role of water on increasing number and size of fruit cells which in turn may affect on fruit size and weight. In this concept similar results were reported by Abd El-hadyetal. (2017) ,El-Zawilyet al.(2019), Liu et al. (2019),Jiansheet al. (2019), Luet al. (2019).

As for the effect of cultivars the same data in table (8) revealed that the cultivars significantly differ in physical fruit quality. Super strain B and Alissa hybrids recorded higher fruit length and diameter than Carmen hybrid in both seasons of study. On the other hand, Carmen hybrid recorded the highest values of fruit length and recorded the lowest values of fruit weight and diameter in both seasons. More ever, cultivars were not significantly affected on fruit firmness in both seasons of study. Such findings might be due to the genetic make- up of the cultivars. Similar varietal differences in fruit length, diameter,weight and firmness reported by Bogaleet al.(2016),Cruzet al.(2019)and Valcárcelet al.(2019).

As for the effect of interaction treatments, data in table (4) indicated that the highest values in most measured physical fruit quality traits ( fruit length and fruit diameter) were obtained by using irrigation every 10 days $\left(2850 \mathrm{~m}^{3} / \mathrm{fed}\right)$ followed by 15 days $\left(2550 \mathrm{~m}^{3} / \mathrm{fed}\right)$ with super strain B and Alissa hybrids in both seasons of study without significant differences between them compared with other treatments in this study. While, Carmen hybrid recorded the highest values of fruit length with irrigation every 10 days followed by irrigation every 15 days with no significant differences among them in both seasons of study. On other hand, the interaction treatments effect for fruit firmness were not significant differ in both seasons and the irrigation treatment with 25 days $\left(2100 \mathrm{~m}^{3} / \mathrm{fed}\right)$ recorded the lowest values of physicals fruit qualities with all cultivars under study in 2017 and 2018 seasons.

\section{Chemical fruit quality:-}

Data presented in table (4) showed the effect of irrigation intervals on chemical fruit quality indices expressed as T.S.S.\%, Vitamin C content and total acidity percentage during the two seasons of study. In this respect, irrigation every 10 days , 15 days and 20 day (irrigation at soil moisture content and \% of field capacity, respectively) recorded the highest values of vitamin $\mathrm{C}$ content in both seasons of study without significant differences among them. While, irrigation every 10 days recorded the highest values of acidity \% in the second season compared with other irrigation treatment under study. On the other hand, irrigation every 25 ( irrigation at soil moisture content and \% of field capacity) followed by irrigation every 20 days recorded the highest values of T.S.S. with no significant differences between them in both seasons of study. However, using irrigation every 25 recorded the lowest values of vitamin $\mathrm{C}$ content and acidity in both seasons of study. This results are in agreement with those obtained by previouslyAbd El-hadyetal. (2017) ,El-Zawilyet al.(2019), Luet al. (2019) and Jiansheet al. (2019).

With regarding the effect of cultivars the same data in table (4) showed clearly that T.S.S \% , vitamin c content and total acidity \% were not significantly improved as a result of using the cultivars effect in both seasons of study expect in the second season, Super strain B recorded the highest values of vitamin .C content compared with other cultivars in this study. Such findings might be due to the genetic make -up of the cultivars .Similar varietal differences inT.S.S $\%$, vitamin c content and total acidity $\%$ were reported by Bogaleet al.(2016), Cruzet al.(2019) andValcárcelet al.(2019).

As for the effect of the interaction treatments between irrigation intervals and hybrids, the same data in table (4) revealed that the highest values of vitamin C (V.C) were recorded as a result of using irrigation every 10 and 15 days( irrigation at soil moisture content and \% of field capacity, respectively ) with super strain B and Alissa hybrids in both seasons of study. More ever, the irrigation every 10 days and 15 days recorded the highest values of vitamin $C$ with super strain B and Alissa hybrids with no significant differences between them in both seasons. On the other hand, irrigation every 25 days $\left(2100 \mathrm{~m}^{3} / \mathrm{fed}\right)$ recorded the lowest values for vitamin $\mathrm{C}$ with all hybrids under study in both seasons. However, irrigation every 20 and 25days( irrigation at soil moisture content and \% of field capacity) gave the highest values of T.S.S \% with all hybrids under study. 
Table 3. Effect of irrigation intervals, hybrids and their interaction on fruit yield and its components of tomato plants grown under Kafr-Elsheikh condition during 2017 and 2018 summer seasons.

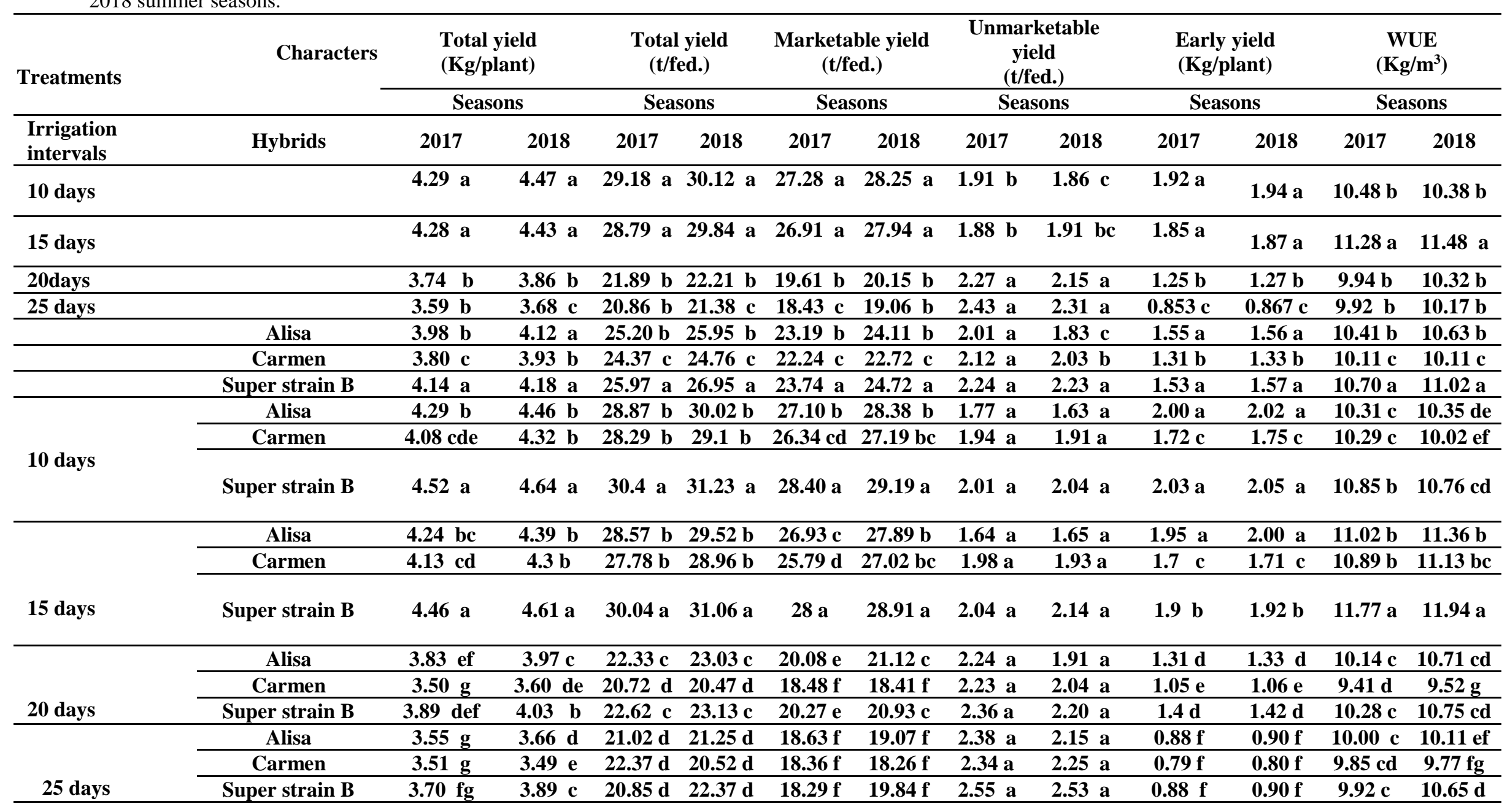


Table 4. Effect of irrigation intervals, hybrids and their interaction on physical and chemical fruit quality of tomato plants grown under Kafr El-sheikh condition during 2017 and 2018 summer seasons.

\begin{tabular}{|c|c|c|c|c|c|c|c|c|c|c|c|c|c|c|c|}
\hline \multirow{3}{*}{$\begin{array}{l}\text { Treatments } \\
\text { Irrigation } \\
\text { intervals }\end{array}$} & \multirow{3}{*}{$\begin{array}{l}\text { Characters } \\
\text { Hybrids }\end{array}$} & \multirow{2}{*}{\multicolumn{2}{|c|}{$\begin{array}{c}\text { Fruit weight (g) } \\
\text { Seasons }\end{array}$}} & \multirow{2}{*}{\multicolumn{2}{|c|}{$\begin{array}{c}\begin{array}{c}\text { Fruit length } \\
(\mathrm{cm})\end{array} \\
\text { Seasons } \\
\end{array}$}} & \multirow{2}{*}{\multicolumn{2}{|c|}{$\begin{array}{c}\begin{array}{c}\text { Fruit diameter } \\
(\mathrm{cm})\end{array} \\
\text { Seasons } \\
\end{array}$}} & \multirow{2}{*}{\multicolumn{2}{|c|}{$\begin{array}{c}\begin{array}{c}\text { Fruit firmness } \\
\left(\mathrm{g} / \mathrm{cm}^{2}\right)\end{array} \\
\text { Seasons }\end{array}$}} & \multirow{2}{*}{\multicolumn{2}{|c|}{$\begin{array}{l}\text { T.S.S \% } \\
\text { Seasons } \\
\end{array}$}} & \multirow{2}{*}{\multicolumn{2}{|c|}{$\begin{array}{c}\text { V.C }(\mathbf{m g} / \mathbf{1 0 0 g}) \\
\text { Seasons }\end{array}$}} & \multirow{2}{*}{\multicolumn{2}{|c|}{$\begin{array}{c}\text { Acidity \% } \\
\text { Seasons } \\
\end{array}$}} \\
\hline & & & & & & & & & & & & & & & \\
\hline & & 2017 & 2018 & 2017 & 2018 & 2017 & 2018 & 2017 & 2018 & 2017 & 2018 & 2017 & 2018 & 2017 & 20181 \\
\hline 10 days & & $139.44 \quad \mathrm{a}$ & 142.22 a & $5.14 \mathrm{a}$ & $5.40 \mathrm{a}$ & $5.22 \mathrm{a}$ & $5.35 \mathrm{a}$ & 370.79 b & 370.83 b & $4.70 \mathrm{~b}$ & $4.78 \mathrm{~b}$ & $3.06 \mathrm{a}$ & $3.15 \mathrm{a}$ & $1.48 \mathrm{a}$ & $1.55 \mathrm{a}$ \\
\hline 15 days & & $137.91 \quad$ a & $134.58 \mathrm{a}$ & $5.10 \mathrm{a}$ & $5.38 \mathrm{a}$ & $5.25 \mathrm{a}$ & $5.34 \mathrm{a}$ & $373.58 \mathrm{~b}$ & $377.5 \quad b$ & $4.55 \mathrm{~b}$ & $4.54 \mathrm{c}$ & $2.97 \mathrm{a}$ & $3.10 \mathrm{a}$ & $1.42 \mathrm{a}$ & $1.44 \mathrm{~b}$ \\
\hline 20days & & $132.77 \mathrm{a}$ & $120.00 \mathrm{~b}$ & $4.95 \mathrm{~b}$ & $5.17 \mathrm{~b}$ & $5.13 \mathrm{a}$ & $5.20 \mathrm{a}$ & 401.62 a & 391.66 a & $5.25 \mathrm{a}$ & $5.3 \mathrm{a}$ & $2.87 \mathrm{a}$ & 3.07 a & $1.23 \mathrm{a}$ & $1.35 \mathrm{~b}$ \\
\hline \multirow[t]{4}{*}{25 days } & & $115.73 \mathrm{~b}$ & $\begin{array}{c}135.10 \\
\mathrm{a}\end{array}$ & $4.68 \mathrm{c}$ & $5.17 \mathrm{~b}$ & $5.22 \mathrm{a}$ & $5.27 \mathrm{a}$ & 434.97 a & 409.56 a & $5.40 \mathrm{a}$ & $5.42 \mathrm{a}$ & $2.14 \mathrm{~b}$ & $2.47 \mathrm{~b}$ & $1.11 \mathrm{a}$ & $1.21 \mathrm{c}$ \\
\hline & Alisa & 136.00 a & 129.89 a & $4.86 \mathrm{~b}$ & $5.23 \mathrm{a}$ & $5.4 \mathrm{a}$ & $5.40 \mathrm{a}$ & $402.05 \mathrm{a}$ & 399.37 a & $4.92 \mathrm{a}$ & $4.97 \mathrm{a}$ & $2.74 \mathrm{a}$ & $2.85 \mathrm{~b}$ & $1.37 \mathrm{a}$ & $1.44 \mathrm{a}$ \\
\hline & Carmen & $121.87 \mathrm{~b}$ & $112.66 \mathrm{~b}$ & $5.16 \mathrm{a}$ & $5.29 \mathrm{a}$ & $4.87 \mathrm{~b}$ & $5.05 \mathrm{~b}$ & 394.96 a & 378.75 a & $4.97 \mathrm{a}$ & $5.03 \mathrm{a}$ & $2.56 \mathrm{a}$ & $2.78 \mathrm{~b}$ & $1.29 \mathrm{a}$ & $1.38 \mathrm{a}$ \\
\hline & Super strain B & 136.48 a & 138.12 a & $4.87 \mathrm{~b}$ & $5.31 \mathrm{a}$ & $5.36 \mathrm{a}$ & $5.41 \mathrm{a}$ & 388.71 a & $400.31 \mathrm{a}$ & $5.02 \mathrm{a}$ & $5.03 \mathrm{a}$ & $2.90 \mathrm{a}$ & $3.21 \mathrm{a}$ & $1.27 \mathrm{a}$ & $1.37 \mathrm{a}$ \\
\hline \multirow[t]{3}{*}{10 days } & Alisa & 145.83 a & 163.33 a & 5.05 bc & $5.3 \mathrm{ab}$ & 5.3 abc & 5.42 bc & $364.95 \mathrm{a}$ & 370 a & $4.59 \mathrm{c}$ & 4.67 bc & $3.4 \mathrm{a}$ & 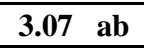 & $1.41 \mathrm{a}$ & $1.47 \mathrm{a}$ \\
\hline & Carmen & $128.33 \mathrm{c}$ & $\begin{array}{c}125.83 \\
\text { bc }\end{array}$ & $5.27 \mathrm{a}$ & $5.32 \mathrm{ab}$ & $4.7 \mathrm{~cd}$ & $4.8 \mathrm{~d}$ & $385.8 \mathrm{a}$ & $372.5 \mathrm{a}$ & $4.82 \mathrm{bc}$ & $4.87 \mathrm{~b}$ & $\begin{array}{l}2.65 \\
\text { abc }\end{array}$ & $2.9 \mathrm{~b}$ & $1.55 \mathrm{a}$ & $1.62 \mathrm{a}$ \\
\hline & Super strain B & $\begin{array}{l}144.16 \\
\text { ab }\end{array}$ & $137.5 \mathrm{ab}$ & $5.1 \mathrm{bc}$ & $5.52 \mathrm{a}$ & $5.67 \mathrm{a}$ & 5.8 a & 361.62 a & 370 a & $4.7 \mathrm{c}$ & $4.8 \mathrm{bc}$ & $3.15 \mathrm{a}$ & $3.5 \mathrm{a}$ & $1.5 \mathrm{a}$ & $1.55 \mathrm{a}$ \\
\hline \multirow{3}{*}{15 days } & Alisa & $144.16 \mathrm{ab}$ & $\begin{array}{c}129.16 \\
\text { bc }\end{array}$ & 5 bed & $5.37 \mathrm{ab}$ & $5.52 \mathrm{ab}$ & $5.6 \mathrm{ab}$ & 399.97 a & 380 a & $4.45 \mathrm{c}$ & $4.45 \mathrm{c}$ & $2.87 \mathrm{ab}$ & $3 \mathbf{a b}$ & $1.47 \mathrm{a}$ & $1.5 \mathrm{a}$ \\
\hline & Carmen & $\begin{array}{c}126.66 \\
\text { cd }\end{array}$ & $\begin{array}{c}113.75 \\
\text { bc }\end{array}$ & 5.27 a & 5.45 a & $\begin{array}{l}5.12 \\
\text { bcd }\end{array}$ & 5.32 bc & 359.15 a & 350 a & $4.45 \mathrm{c}$ & $4.55 \mathrm{bc}$ & 3.1 ab & $2.75 \mathrm{bc}$ & $1.3 \mathrm{a}$ & $1.35 \mathrm{a}$ \\
\hline & Super strain B & 142.9 ab & 160.83 a & 5.02 bcd & 5.37 ab & $\begin{array}{l}5.12 \\
\text { bed }\end{array}$ & $5.15 \mathrm{~cd}$ & 361.62 a & 392.5 a & $4.75 \mathrm{c}$ & $4.62 \mathrm{bc}$ & $2.95 \mathrm{ab}$ & $3.55 \mathrm{a}$ & $1.5 \mathrm{a}$ & $1.47 \mathrm{a}$ \\
\hline \multirow{3}{*}{20 days } & Alisa & $137.5 \mathrm{~b}$ & $\begin{array}{c}126.66 \\
\text { cd }\end{array}$ & 4.87 de & 5.17 bc & $5.35 \mathrm{ab}$ & $5.2 \mathrm{bcd}$ & 399.95 a & 380 a & $5.25 \mathrm{ab}$ & 5.32 a & $2.6 \mathrm{abc}$ & $3.02 \mathrm{ab}$ & $1.45 \mathrm{a}$ & $1.5 \mathrm{a}$ \\
\hline & Carmen & $\begin{array}{c}120.83 \\
\text { de }\end{array}$ & $106.66 \mathrm{c}$ & $5.15 \mathrm{ab}$ & $5.2 \mathrm{bc}$ & $\begin{array}{l}5.00 \\
\text { bed }\end{array}$ & $5.02 \mathrm{~cd}$ & 382.45 a & 385 a & $5.25 \mathrm{ab}$ & $5.3 \mathrm{a}$ & $\begin{array}{l}2.62 \\
\text { abc }\end{array}$ & 3.17 ab & 1.32 a & $1.4 \mathrm{a}$ \\
\hline & Super strain B & $\begin{array}{c}140.00 \\
\text { ab }\end{array}$ & $\begin{array}{c}160.83 \\
\text { bc }\end{array}$ & $4.82 \mathrm{e}$ & 5.15 bc & 5.32 abc & 5.37 bc & 422.47 a & $410 a$ & $5.25 \mathrm{ab}$ & $5.27 \mathrm{a}$ & $3.41 \mathrm{a}$ & $3.02 \mathrm{ab}$ & 0.925 a & $1.15 \mathrm{a}$ \\
\hline \multirow[t]{3}{*}{25 days } & Alisa & 116.66 ef & $\begin{array}{c}121.25 \\
\text { bc }\end{array}$ & $4.55 \mathrm{f}$ & $5.1 \mathrm{c}$ & $5.42 \mathrm{ab}$ & $5.4 \mathrm{bc}$ & 443.32 a & 437.5 a & $5.42 \mathrm{a}$ & $5.45 \mathrm{a}$ & $2.11 \mathrm{bc}$ & $2.32 \mathrm{c}$ & $1.17 \mathrm{a}$ & $1.3 \mathrm{a}$ \\
\hline & Carmen & $111.66 \mathrm{f}$ & $104.16 \mathrm{c}$ & $\begin{array}{l}4.95 \\
\text { cde }\end{array}$ & $5.2 \mathrm{bc}$ & $4.65 \mathrm{~d}$ & $5.07 \mathrm{~cd}$ & 452.47 a & 387.5 a & $5.37 \mathrm{a}$ & $5.4 \mathrm{a}$ & $1.87 \mathrm{c}$ & $2.3 \mathrm{c}$ & 0.987 a & $1.17 \mathrm{a}$ \\
\hline & Super strain B & 118.86 ef & 127.5 bc & $4.55 \mathrm{f}$ & $5.22 \mathrm{bc}^{\prime}$ & 5.32 abc & 5.35 bc & 409.12 a & 403.7 a & $5.4 \mathrm{a}$ & $5.42 \mathrm{a}$ & $\begin{array}{l}2.45 \\
\text { abc }\end{array}$ & $2.8 \mathrm{bc}$ & $1.18 \mathrm{a}$ & $1.17 \mathrm{a}$ \\
\hline
\end{tabular}


References

A.O.A.C. 1990.Official methods of analysis.Association of official analytical chemists. $15^{\text {th }}$ ed. Washington D.C., USA.

Abdalaali, H.H., C.H. Abdul-Jabar and A.M. Abdulkareem (2012).Effect of mulching , irrigation regime and $\mathrm{N}$ fertilization on dry weight and $\mathrm{N}$-uptake of tomato plant.

Abdelhady S.A., N.A.I. Abu El-Azm and S.H. ElKafafi (2017). Effect of deficit irrigation levels and NPK fertilization rates on tomato growth, yield and fruits quality. J. Agric. Res. (03):587604.

Aghaie P., S.A.H. Tafreshi, M.A. Ebrahimi and M. Haerinasab (2018).Tolerance evaluation and clustering of fourteen tomato cultivars grown under mild and severe drought conditions. J. Sci. Hort. 232 : 1-12.

Bates, L.S., R.P. Waldern and I.D. Teare1973. Rapid determination of free proline water stress studies. Plant and Soil,39: 205-207.

Black, C.A., D.O. Evans, LE.Ensminger, J.L. White, F.E. Clark and R.C. Dinauer (1982).Methods of soil analysis.part 2. Chemical and microbiological properties.2nd ed. Soil Sci., Soc. of Am. Inc. Publ., Madison, Wisconsin, U. S.A.

Brown, J. and O. Lilleland (1946). Rapid determination of potassium and sodium in plant material and soil extracts by flame photometric. Proc. Amer. Soc. Hort. Sci., 48: 341- 346.

Cherry, J.H. (1973): Molecular biology of plants test-Manual. Clombia Univ. Press. New York and London 68-71.

Cruz, C. E., Martínez, M. A. J., Moriana, A., Girón, I. F., Palomo, M. J. M., Galindo, A., Lópezg, P. D., Torrecillas, A., Sinchiguano, B. E. and Corell, M., 2019. Yield response to regulated deficit irrigation of greenhouse cherry tomatoes.J. Agric., Water Management (213): 212-221.

El-Zawily A. S., M. Meleha, M. El-Sawya, H. ElAttarb, Y. Bayoumia, T. Alshaal (2019). Application of magnetic field improves growth, yield and fruit quality of tomato irrigated alternatively by fresh and agricultural drainage water. Ecotoxicology and Environmental Safety (181): 248-254.

Jackson, M.L. (1973). Soil Chemical Analysis.Printice-Hall of India.Privat Limited, New Delhi.

Jianshe L., Y. Gaoa, X. Zhanga, P. Tiana, J. Lia and Y. Tiana (2019). Comprehensive comparison of different saline water irrigation strategies for tomato production: Soil properties, plant growth, fruit yield and fruit quality. Agric. Water Management, $213: 521-533$
John, M.K. (1970).Colorimetric determination of phosphorus in soil and plant material with ascorbic acid. Soil Sci., 109: 214-220.

Kirda, C. 2002. Deficit irrigation scheduling based on plant growth stages showing water stress tolerance. Deficit irrigation practices. In: FAO Corp. Doc. Rep. 22, Rome, 3-10.

Lgbadun, H.E., B.A. Salim, A.K.P.R. Tarimo and H.F. Mahoo. 2008. Effect of deficit irrigation Scheduling on yields and soil water balance of irrigated maize. Irrigation Sci., 27: 11-23.

Liu, H., Li, H., Ning, H., Zhang, X., Li, S., Pang, J., Wang, G. and Sun, J., 2019 Optimizing irrigation frequency and amount to balance yield, fruit quality and water use efficiency of greenhouse tomato.J.Agric., Water Management (226) :105787.

Lu, J., Shao, G., Cui, J., Wang, X. and Keabetswe, L.(2019) Yield, fruit quality and water use efficiency of tomato for processing under regulated deficit irrigation: A metaanalysis. J. Agric., Water Management (222): 301-312.

Luvai A.K., A.N. Gitau, B.N.K. Njoroge and J.P.O. Obiero 2014.Effect of water application levels on growth characteristics and soil water balance of tomatoes in green house.International Journal of Engineering Innovation, Res. 3: 271- 278.

Malash , N.M., M.A. Fattahalla, M.R. Khalil and E.S.A. Ibrahim 2019. Enhancing drought tolerance of tomato plants grown under different irrigation regimes by some cultural practices. .Menoufia J. Plant prod., 4 (6) :181-205.

Murquard, R. D. and J. L. Timpton (1987). Relationship between extractable chlorophyll and an in-situ method to estimate leaf green. Hort. Sci., 22(6): 1327.

Oweis, T. and A. Hachum. 2001. Reducing peak supplemental irrigation demand by extending sowing dates. Agric. Water Management, 50:109 -124 .

Pazzaglia T. P., J. Weinerband F. Liua (2016). Effects of $\mathrm{CO} 2$ elevation and irrigation regimes on leaf gas exchange, plant water relations, and water use efficiency of two tomato cultivars. Agric. Water Management.,(169) : 26-33.

Pereira, L.S., T. Oweis and A. Zairi. 2002. Irrigation management under water scarcity. Agric. Water Management, 57: 175-206.

Pregl, E. (1945).Quantitative organic micro analysis. $4^{\text {th }}$ ed. J. Chundril, London.

RahilM., H. Hajjehand A. Qanadillo.(2013) Effect of Saline Water Application through Different Irrigation Intervals on Tomato Yield and Soil Properties. J. Soil Science, 3: 143-147.

Topcu, S., Kidra, C., Dasgan, Y., Kaman, H., Cetin, M., Yazici, A. and M. A. Bacon. 2007. Yield response and $\mathrm{N}$-fertilizer recovery of tomato grown under deficit irrigation. Eur. J. of Agro., 26: 64-70. 
Valcárcel, M., Lahoz, I., Campillo, C., Martí R., Brondo, L. M., Rosello, S. and Cornejo, C. J., 2019 Controlled deficit irrigation as a watersaving strategy for processing tomato.J. Sci. Horti., https://doi.org/10.1016/j.scienta.2019.108972.

Whab-Allah, M.A. and A.M. AlOmran(2012).Effect of water quality and deficit irrigation on tomato growth, yield and water use efficiency at different developmental stages. J. Agric. Env. Dam. Univ., Egypt. 11(2): 80-110.

Zhu, J., L. Yinli, Y. Zhu, W. Hao, X. Lin, X. Wu and A. Luo (2012). The interactive effects of water and fertilizer on photosynthetic capacity and yield in tomato plants. AJCS, 6(2):200-209.

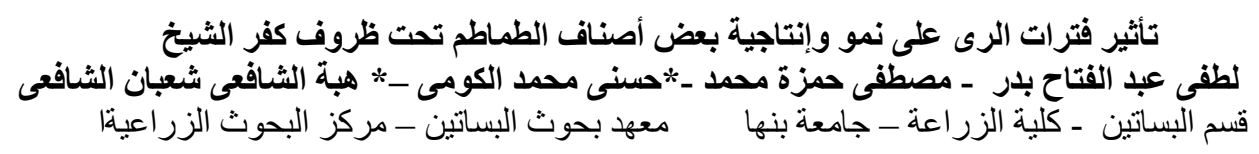

اجريت تجربتان حقليتان بمزر عة خاصة بمحافظة كفر الثيخ خلال الموسم الصيفى لعام 2017 و 2018 وذلك لدر استة تاثيثرفترات

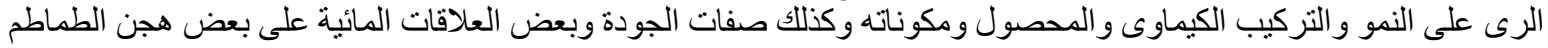
المنزر عة تحت ظروف محافظة كفر الثيخ.

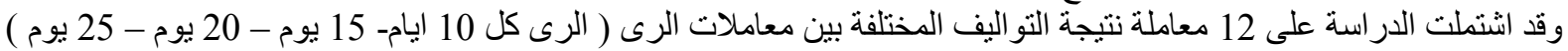

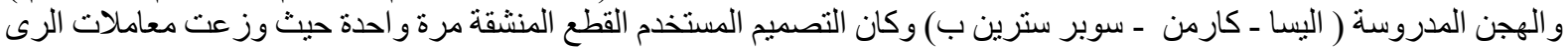





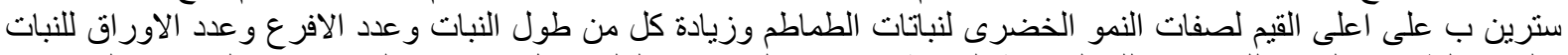

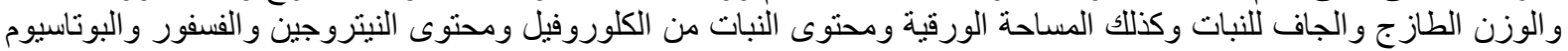

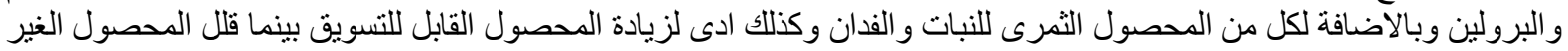

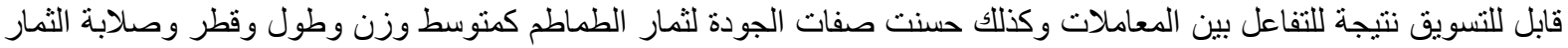

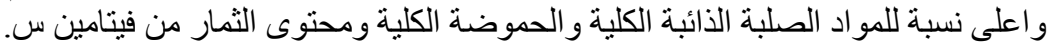

